\title{
Short Communication: Species composition and diversity of vegetation in dryland agricultural landscape
}

\author{
IDA ARDIYANINGRUM ${ }^{1, \boldsymbol{v}}$, MARIA THERESIA SRI BUDIASTUTI ${ }^{2}$, KOMARIAH $^{\mathbf{3}}$ \\ ${ }^{1}$ Program of Environmental Science, Graduate School, Universitas Sebelas Maret. J1. Ir. Sutami 36A, Surakarta 57126, Central Java, Indonesia \\ Tel.: +62-271-632450, `email: ardianida@ rocketmail.com \\ ${ }^{2}$ Department of Agrotechnology, Faculty of Agriculture, Universitas Sebelas Maret. J1. Ir. Sutami 36A, Surakarta 57126, Central Java, Indonesia \\ ${ }^{3}$ Department of Soil Science, Faculty of Agriculture, Universitas Sebelas Maret. Jl. Ir. Sutami 36A, Surakarta 57126, Central Java, Indonesia
}

Manuscript received: 14 September 2020. Revision accepted: 10 December 2020.

\begin{abstract}
Ardiyaningrum I, Budiastuti MTS, Komariah. 2021. Short Communication: Species composition and diversity of vegetation in dryland agricultural landscape. Biodiversitas 22: 65-71. Drylands are a part of the terrestrial ecosystems with a relatively larger area compared to wetlands. Selo has dryland with steep slopes and high rainfall, resulting in relatively high soil erosion. The land use in this sub-district is dominated by plantations and agriculture, with conditions that have not been fully balanced by trees as a means of controlling erosion and supporting vegetation diversity. Therefore, studies on biodiversity are important as an indicator of dryland sustainability, especially in terms of soil and water conservations. This research aimed to study the species composition and diversity of vegetation in the dryland agricultural landscape in Selo Sub-district, Boyolali District, Central Java Province, Indonesia. Vegetation analysis was performed by using the quadratic sampling technique for tree category, pole category, sapling category, and seedling categories. The results indicated that Fabaceae had the highest number of species. Tree species with the highest Importance Value Index were Toona sureni, Artocarpus heterophyllus, and Casuarina junghuhniana, respectively. The Shanon-Wiener Diversity Index showed that the vegetation at tree, pole, and sapling stages had a moderate diversity, and seedling-stage vegetation had a low diversity.
\end{abstract}

Keywords: Conservation, erosion, dryland, Selo Sub-district, Toona sureni, vegetation analysis

\section{INTRODUCTION}

Drylands are a part of the terrestrial ecosystem with a relatively larger area compared to wetlands. There are various limiting factors of dryland use, including soil erosion, topography, and water availability. The use of drylands for agriculture regardless of conservation principles will lead to erosion and decrease soil fertility. Continuing land degradation will cause the lands to be critical and disturb their ecosystem balance. According to Akinyemi and Kgomo (2019), degraded drylands will have low diversity and species richness. Vegetation diversity is the key to the stability of dryland ecosystems. High vegetation diversity can increase the ability of an ecosystem to maintain stability under climate fluctuations (Geng et al. 2019)

Selo is a mountainous area on the slopes between Mount Merapi and Mount Merbabu. The valley between the two mountains is an area that is widely used as agricultural land (Nurhadi et al. 2019). Selo has tiled to steep slopes. The slopes in Selo Sub-district are twice as steep as those in Mojosongo Sub-district and Boyolali Subdistrict of Boyolali District, Indonesia. Selo has a wet climate as it has a high annual rainfall up to $2.801 \mathrm{~mm} /$ year in 2018 (BPS 2019). Steep slope conditions and a high rainfall cause a high level of erosion hazard. A steeper slope results in a greater surface runoff strength which has the potential to cause erosion (Zhang et al. 2018).
Dryland in Selo is used as a dry fields/ gardens $(1,926.3$ ha), state forest (1,350.6 ha), yard/ building (999.3 ha), pastureland (800 ha), and others (496.2 ha) (BPS 2019). Land use in agricultural landscapes is dominated by plantations and dry fields. Land use in the form of dry fields with a slope of $31 \%$ in Jeruk Village, Selo, has a high erosion of 284.75 tons/ha/year (Syahidah et al. 2016) Land cover affects the amount of soil erosion. Areas with a smaller land cover have a higher risk of soil erosion than those with greater land cover (Wijitkosum 2012). Areas protected by green vegetation have a low risk of soil erosion, even with steep slopes and a high annual rainfall (Ochoa et al. 2016) Erosion will also increase in monoculture farming systems (Donia et al. 2019)

Vegetation plays an important role in controlling soil erosion (Zhao et al. 2015). Vegetation controls soil erosion with canopies, roots, and litter, but erosion affects vegetation in terms of composition, structure, and growth patterns of plant communities (Gyssels et al. 2005). The erosion rate will decrease depending on the structure and composition of plants in the area. The morphology and structure of vegetation become the priority in controlling erosion (Miri et al. 2017). Higher species richness can reduce annual soil erosion rates (Song et al. 2019)

The land use in Selo is dominated by plantations and agriculture, with conditions that have not been fully balanced by trees as a means of controlling erosion and supporting vegetation diversity. Therefore, studies on 
biodiversity are important. This analysis of vegetation in this study was conducted to investigate the species composition and diversity of vegetation in the dryland agricultural landscape in Selo Sub-district, Boyolali District, Central Java Province, Indonesia.

\section{MATERIALS AND METHODS}

\section{Study area}

This study was carried out in the dryland agricultural landscape in Selo Sub-district, Boyolali District, Central Java Province, Indonesia (Figure 1). The location is on the slopes between Mount Merapi and Merbabu with an altitude of 1200-1500 m asl. The study was conducted from January to February 2020.

\section{Procedure}

The sampling location was determined purposively based on land use of dry fields/gardens. There were 12 sampling stations or locations with a total area of 1.4 hectares. At each location, 3 replications were carried out, resulting in 36 plots for each type of vegetation. Vegetation analysis was performed by using quadratic sampling technique with a size of $20 \mathrm{~m} \times 20 \mathrm{~m}$ for the tree category, $10 \mathrm{~m} \times 10 \mathrm{~m}$ for the pole category, $5 \mathrm{~m} \times 5 \mathrm{~m}$ for the sapling category, and $2 \mathrm{~m} \times 2 \mathrm{~m}$ for the seedlings category (Kusmana 2017).

\section{Data analysis}

The vegetation data were analyzed quantitatively. The importance of a plant species and its role in the community was obtained by calculating the Importance Value Index (IVI). IVI is the sum of Relative Density (RD), Relative Frequency (RF), and Relative Dominance (RDo) (Curtis and McIntosh, 1951). IVI for seedling is the sum of RD and RF (Soerianegara and Indrawan 2002). The equation used follows that of Soerianegara and Indrawan (2002).

Density $(\mathrm{D})=\frac{\text { Total number of individuals }}{\text { Total plot area }}$

Relative Density $(\mathrm{RD})=\frac{\mathrm{D} \text { of a species }}{\mathrm{D} \text { of all species }} \times 100 \%$

Frequency $(F)=\frac{\text { Number of plots where a species is found }}{\text { Number of total plots }}$

Relative Frequency $(R F)=\frac{F \text { of a species }}{F \text { of all species }} X 100 \%$

Dominance $($ Do $)=\frac{\text { Basal area of a species }}{\text { Total plot area }}$

Relative Dominance (RDo) $=\frac{\text { Do of a species }}{\text { Do of all species }} \times 100 \%$

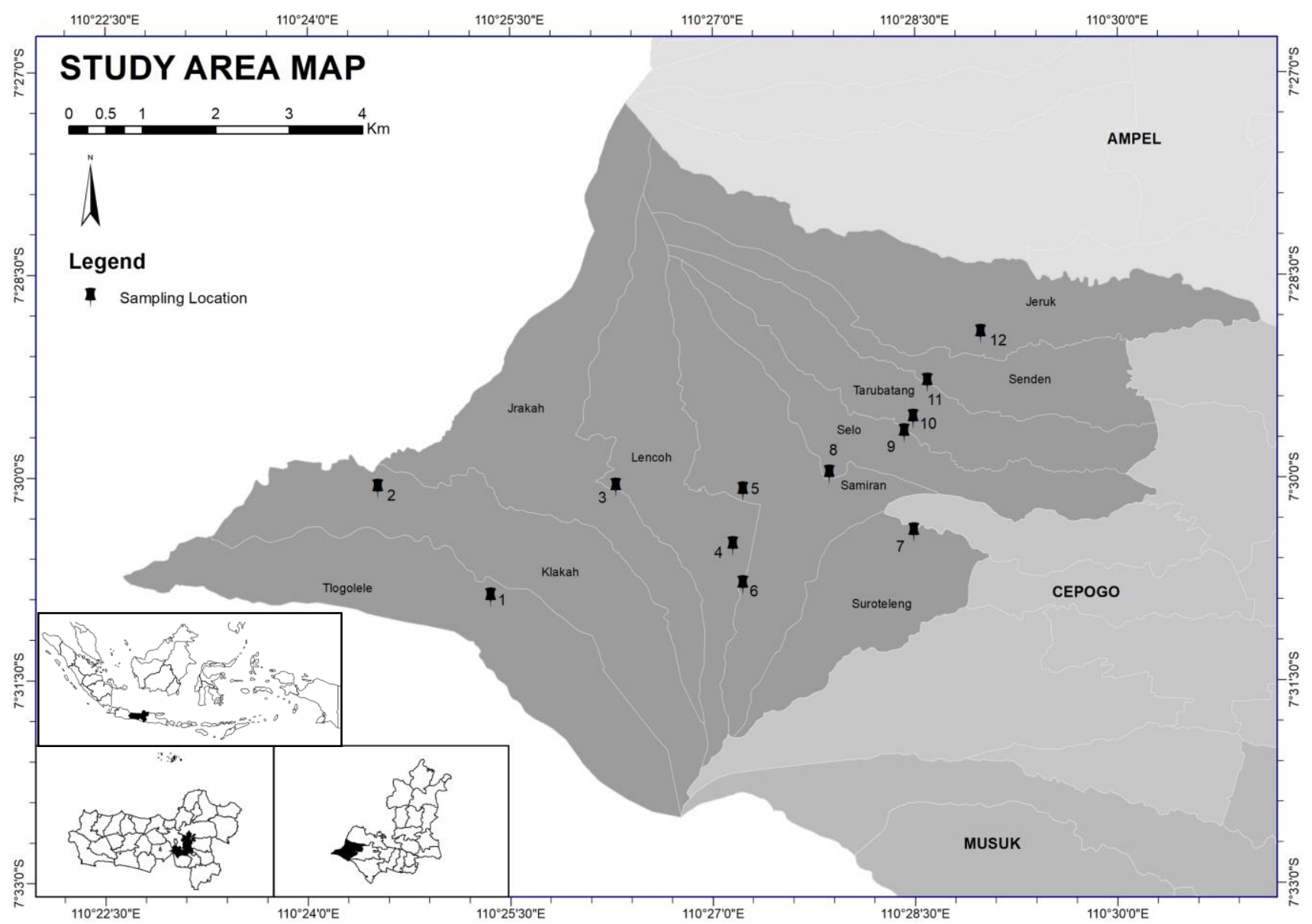

Figure 1. The study area map in Selo Sub-district, Boyolali District, Central Java Province, Indonesia 
The vegetation diversity index was calculated by using the Shannon-Wiener Diversity Index formula:

$$
H^{\prime}=-\sum_{i=1}^{n}\left[\left(\frac{n i}{N}\right) \ln \left(\frac{n i}{N}\right)\right]
$$

Where:

$\mathrm{H}^{\prime} \quad$ : Diversity index

ni : Number of individuals of each species

$\mathrm{N}$ : Total number of individuals

The dominance index was calculated by using the Simpson dominance index formula.

$$
D=\sum\left(\frac{\mathrm{ni}}{\mathrm{N}}\right)^{2}
$$

Where:

$$
\begin{array}{ll}
\mathrm{D} & \text { : Dominance index } \\
\mathrm{ni} & \text { : Number of individuals of each species } \\
\mathrm{N} & \text { : Total number of individuals }
\end{array}
$$

\section{RESULTS AND DISCUSSION}

\section{Species composition}

Table 1 shows the composition of plant species at 12 sampling locations. There were 19 species of plants from 11 families consisting of growth stages of trees, poles, saplings, and seedlings. The families with the highest number of species included Fabaceae ( 5 species). Species from the Fabaceae family are widely used by the surrounding community for greening. Meanwhile, those with the fewest species included Casuarinaceae, Euphorbiaceae, Lauraceae, Malvaceae, Myrtaceae, and Pinaceae (1 species each).

The species of the Fabaceae family dominated with a total of 59 individuals, which was followed by 49 individuals of Rubiaceae, and 33 individuals of Meliaceae. Coffea arabica had the highest number of individuals i.e. 36, which was followed by Paraserianthes lophantha and Toona sureni of 29 each. Glochidion rubrum, Samanea saman, Cinnamomum verum, Ficus racemosa, and Syzygium myrtifolium were the rarest species.

Figure 2 shows that the sapling stage obtained the highest density of 955.56 individuals $\mathrm{ha}^{-1}$, which was followed by seedling stage of 694.44 individuals $\mathrm{ha}^{-1}$, pole stage of 147.27 individuals $\mathrm{ha}^{-1}$, and the lowest density at the tree stage of 37.5 individuals $\mathrm{ha}^{-1}$. Based on the density of each stage, vegetation in the dryland agricultural landscapes had a poor regeneration characterized by a lower density of seedlings than the sapling stage. Seedlings are an important indicator of the continuation of regeneration (Susilowati et al. 2020). The regeneration status is good if the seedling density $>$ the sapling stage density > mature tree stage density (Shankar 2001; Saikia and Khan 2016).

\section{Tree stage}

The total density for the tree stage was 37.5 individuals $\mathrm{ha}^{-1}$. T. sureni had the highest relative density of $29.63 \%$ followed by Artocarpus heterophyllus of $18.52 \%$ and Acacia decurens of $16.67 \%$ (Tabel 2). Meanwhile, Albizia chinensis, Hibiscus macrophyllus, Melia azedarach, and $P$. lophantha had the lowest relative density of $3.70 \%$ each. The tree stage density was low compared to other regions such as those in Sigi District, Central Sulawesi, Indonesia with a density of 572.67 individuals ha $^{-1}$ (Lestari et al. 2018).

Toona sureni had the highest IVI (71.49) at the tree stage, followed by A. heterophyllus (60.6) and Casuarina junghuhniana (50.85), while M. azedarach had the lowest IVI (9.59). T. sureni is a type of tree planted by people in Selo. It has a diameter of up to $100 \mathrm{~cm}$ (Latifah et al. 2018) and produces good quality woods with a high economic value (Latifah et al. 2019).

\section{Pole stage}

The total density for the pole stage was 147.44 individuals $\mathrm{ha}^{-1}$. $P$. lophantha contributed the highest relative density of $18.87 \%$ which was followed by $T$. sureni of $16.98 \%$ and Cinchona pubescens of $15.09 \%$, while Cinnamomum verum, F. racemosa, G. rubrum, Leucaena leucocephala, Pinus merkusii, and Syzygium myrtifolium had the lowest relative density of $1.89 \%$ each (Tabel 3). $P$. lophantha is an annual plant useable as a building material and shade plant (Hakim et al. 2019).

Paraserianthes lophantha had the highest IVI (50.61) at the pole stage, followed by T. sureni (48.65) and Acacia decurens (43.21), while Syzygium myrtifolium and $M$. azedarach had the lowest IVI of 5.13 each. Several exotic species were found, but some plants could become invasive species (Ismail et al. 2019). Acacia decurens is an invasive plant species in Mount Merapi National Park (Sunardi et al. 2017). It is one type of species that grows fast, spreads, and is dominant (Suryawan et al. 2015).

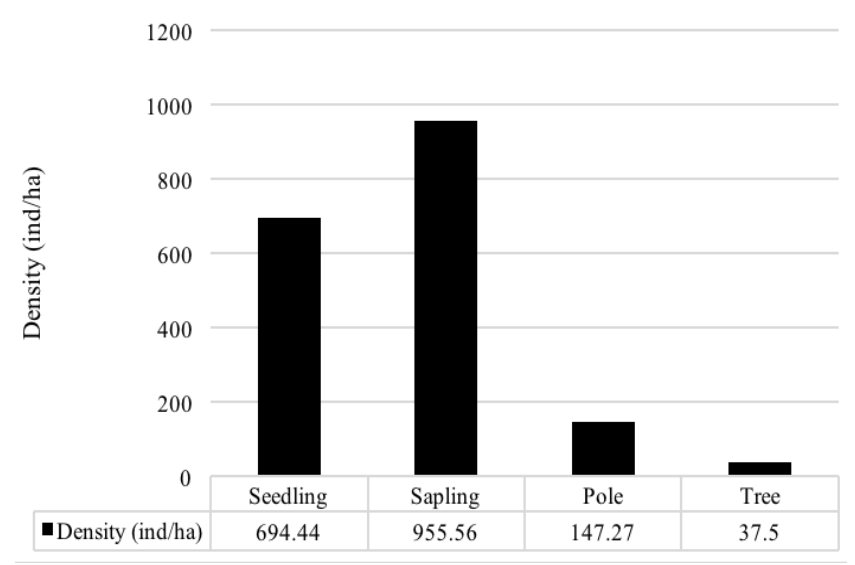

Figure 2. The density of vegetation in dryland agricultural landscape 
Table 1. Species composition in dryland agricultural landscape

\begin{tabular}{|c|c|c|c|}
\hline Family & Plant species & Number of individuals & $\begin{array}{c}\text { Total number of } \\
\text { individual }\end{array}$ \\
\hline Casuarinaceae & Casuarina junghuhniana Miq. & 26 & 26 \\
\hline Euphorbiaceae & Glochidion rubrum $\mathrm{Bl}$ & 1 & 1 \\
\hline \multirow[t]{5}{*}{ Fabaceae } & Albizia chinensis (Osbeck) Merr & 2 & 59 \\
\hline & Acacia decurrens (Wendl. f.) Wild. & 25 & \\
\hline & Paraserianthes lophantha (Wild.) I.C. Nielsen & 29 & \\
\hline & Leucaena leucocephala (Lam.) de Wit & 2 & \\
\hline & Samanea saman (Jacq.) Merr. & 1 & \\
\hline Lauraceae & Cinnamomum verum J.S. Presl. & 1 & 1 \\
\hline Malvaceae & Hibiscus macrophyllus Roxb. Ex Hornem. & 7 & 7 \\
\hline \multirow[t]{2}{*}{ Meliaceae } & Melia azedarach $\mathrm{L}$. & 4 & 33 \\
\hline & Toona sureni (Blume) Merr. & 29 & \\
\hline \multirow[t]{2}{*}{ Moraceae } & Artocarpus heterophyllus Lam & 14 & 15 \\
\hline & Ficus racemosa $\mathrm{L}$. & 1 & \\
\hline Myrtaceae & Syzygium myrtifolium Walp. & 1 & 1 \\
\hline Pinaceae & Pinus merkusii Jungh. \& Vriese ex Vriese & 4 & 4 \\
\hline \multirow[t]{2}{*}{ Rubiaceae } & Cinchona pubescens Vahl & 13 & 49 \\
\hline & Coffea arabica $\mathrm{L}$. & 36 & \\
\hline \multirow[t]{2}{*}{ Theaceae } & Schima wallichii (DC.) Korth. & 4 & 7 \\
\hline & Camellia sinensis (L.) Kuntze & 3 & \\
\hline
\end{tabular}

Table 2. Vegetation analysis of tree stage

\begin{tabular}{lcccc}
\hline Plant species & RD & RF & RDo & IVI \\
\hline Acacia decurrens (Wendl. f.) Wild. & 16.67 & 13.33 & 7.79 & 37.79 \\
Albizia chinensis (Osbeck) Merr & 3.70 & 6.67 & 1.86 & 12.23 \\
Artocarpus heterophyllus Lam & 18.52 & 20.00 & 22.08 & 60.60 \\
Casuarina junghuhniana Miq. & 9.26 & 6.67 & 34.92 & 50.85 \\
Cinchona pubescens Vahl & 5.56 & 10.00 & 2.89 & 18.45 \\
Hibiscus macrophyllus Roxb. Ex Hornem. & 3.70 & 6.67 & 1.72 & 12.09 \\
Melia azedarach L. & 3.70 & 3.33 & 2.55 & 9.59 \\
Paraserianthes lophantha (Wild.) I.C. Nielsen & 3.70 & 3.33 & 4.48 & 11.52 \\
Pinus merkusii Jungh. \& Vriese ex Vriese & 5.56 & 6.67 & 3.18 & 15.40 \\
Toona sureni (Blume) Merr. & 29.63 & 23.33 & 18.53 & 71.49 \\
\hline
\end{tabular}

Note: RD: Relative Density (\%), FR: Relative Frequency (\%), RDo: Relative Dominance (\%), IVI: Important Value Index

Table 3. Vegetation analysis of pole stage

\begin{tabular}{lcccc}
\hline Plant species & RD & RF & RDo & IVI \\
\hline Acacia decurens (Wendl. f.) Wild. & 11.32 & 13.95 & 17.94 & 43.21 \\
Artocarpus heterophyllus Lam & 3.77 & 4.65 & 3.63 & 12.05 \\
Casuarina junghuhniana Miq. & 11.32 & 6.98 & 13.16 & 31.46 \\
Cinchona pubescens Vahl & 15.09 & 11.63 & 14.39 & 41.12 \\
Cinnamomum verum J.S. Presl. & 1.89 & 2.33 & 1.81 & 6.02 \\
Ficus racemosa L. & 1.89 & 2.33 & 2.06 & 6.27 \\
Glochidion rubrum Bl & 1.89 & 2.33 & 1.81 & 6.02 \\
Hibiscus macrophyllus Roxb. Ex Hornem. & 5.66 & 6.98 & 8.31 & 20.95 \\
Leucaena leucocephala (Lam.) de Wit & 1.89 & 2.33 & 1.29 & 5.51 \\
Melia azedarach L. & 1.89 & 2.33 & 0.92 & 5.13 \\
Paraserianthes lophantha (Wild.) I.C. Nielsen & 18.87 & 20.93 & 10.81 & 50.61 \\
Pinus merkusi Jungh. \& Vriese ex Vriese & 1.89 & 2.33 & 1.10 & 5.31 \\
Schima wallichii (DC.) Korth. & 3.77 & 4.65 & 4.13 & 12.56 \\
Syzygium myrtifolium Walp. & 1.89 & 2.33 & 0.92 & 5.13 \\
Toona sureni (Blume) Merr. & 16.98 & 13.95 & 17.71 & 48.65 \\
\hline
\end{tabular}


Table 4. Vegetation analysis of sapling stage

\begin{tabular}{lcccc}
\hline Plant species & RD & RF & RDo & IVI \\
\hline Acacia decurens (Wendl. f.) Wild. & 11.63 & 11.76 & 11.03 & 34.42 \\
Artocarpus heterophyllus Lam & 2.33 & 2.94 & 5.31 & 10.57 \\
Casuarina junghuhniana Miq. & 17.44 & 11.76 & 24.25 & 53.46 \\
Cinchona pubescens Vahl & 2.33 & 5.88 & 0.99 & 9.20 \\
Coffea arabica L. & 34.88 & 20.59 & 26.45 & 81.92 \\
Hibiscus macrophyllus Roxb. Ex Hornem. & 2.33 & 2.94 & 3.55 & 8.81 \\
Leucaena leucocephala (Lam.) de Wit & 1.16 & 2.94 & 1.28 & 5.38 \\
Melia azedarach L. & 1.16 & 2.94 & 2.23 & 6.33 \\
Paraserianthes lophantha (Wild.) I.C. Nielsen & 18.60 & 17.65 & 11.77 & 48.02 \\
Samanea saman (Jacq.) Merr. & 1.16 & 2.94 & 0.53 & 4.63 \\
Schima wallichii (DC.) Korth. & 2.33 & 5.88 & 2.31 & 10.52 \\
Toona sureni (Blume) Merr. & 4.65 & 11.76 & 10.31 & 26.73 \\
\hline
\end{tabular}

\section{Sapling stage}

The total density for the sapling stage was 955.56 individuals $\mathrm{ha}^{-1}$. Coffea arabica contributed the highest relative density of $34.88 \%$, which was followed by $P$. lophantha of $18.6 \%$ and Casuarina junghuhniana of $17.44 \%$, while L. leucocephala, M. azedarach, and S. saman had the lowest relative density of $1.16 \%$ each (Tabel 4 ).

Coffea arabica had the highest IVI (81.92) at the sapling stage, followed by $C$. junghuhniana (53.46) and $P$. lophantha (48.02). Meanwhile, S. saman had the lowest IVI (4.63). C. arabica is a commodity developed in the agroforestry system in Selo. Some agroforestry systems can be found in agricultural landscapes dominated by vegetable gardens. Sepulveda and Carrillo (2015) stated that coffee agroforestry systems have been proven to reduce erosion and are effective in terms of soil conservation in tropical highlands.

\section{Seedling stage}

The total density for the seedling stage was 694.44 individuals $\mathrm{ha}^{-1}$. C. arabica had the highest relative density of $60 \%$, which was followed by Camellia sinensis of $30 \%$ and $P$. lophantha of $10 \%$ (Tabel 5). C. arabica also had the highest IVI (93.33) at the seedling stage, followed by $C$. sinensis (80), while $P$. lophantha has the lowest IVI (26.67). There was a decrease in density and number of species at the seedling stage because the level of community participation in conservation was low. Fitria and Banowati (2018) stated that the low level of community participation in Tlogolele Village, Selo Subdistrict, was due to the fact that many plants were not planted, which made the agroforestry program not run efficiently.

\section{Vegetation diversity}

The Shannon-Wiener Diversity Index showed that the diversity of trees, poles, and saplings in Selo was in the moderate category with the values of 2.00 for tree stage, 2.33 for pole stage, 1.88 for sapling stage (Table 6). This indicates that the ecosystem is quite balanced. Odum (1971) stated that the diversity value $1 \leq \mathrm{H}^{\prime} \geq 3$ indicates moderate diversity, distribution, and community stability of a region. High species diversity in an ecosystem is more likely to increase the stability of the plant community, and vice versa (Boeck et al. 2018).

The diversity of seedling stage was in the low category with the value of 0.87 . Only three species were found in the seedling stage, affecting the low diversity index. Yudaputra and Rahardjo (2020) stated that the high or low value of the diversity index is influenced by the number of species and individuals found. The lower value of the diversity index of a region reflects the instability of the community.

No vegetation with a high diversity index was found on the dryland agricultural landscape. This is because the community, especially farmers, are more concerned with high yields on their agricultural land. They think that planting a large number of trees will reduce land productivity; they do not consider the sustainability of the land in the future. Intensification of agricultural land is the main reason for the decline in biodiversity and the provision of ecosystem services (Tarigan 2019; Hall et al. 2020). Also, farmers only rely on tree seedlings from the government without conducting independent seedlings.

The Simpson dominance index ranged from 0.17 to 0.46 . Seedling vegetation had the highest dominance index while pole vegetation has the lowest. The dominance index affects species diversity (Yam and Tripathi 2016). A high dominance index indicates a low diversity. The higher the value of the dominance index is, the lower the diversity index will be (Ulfah et al. 2019).

Table 5. Vegetation analysis of seedling stage

\begin{tabular}{lccc}
\hline Plant species & RD & RF & IVI \\
\hline Camellia sinensis (L.) Kuntze & 30.00 & 50.00 & 80.00 \\
Coffea arabica L. & 60.00 & 33.33 & 93.33 \\
Paraserianthes lophantha (Wild.) & 10.00 & 16.67 & 26.67 \\
I.C. Nielsen & & & \\
\hline
\end{tabular}

Table 6. Vegetation diversity and dominance index in all growth stage

\begin{tabular}{lcc}
\hline Growth stage & $\begin{array}{c}\text { Diversity index } \\
\left(\mathbf{H}^{\prime}\right)\end{array}$ & $\begin{array}{c}\text { Dominance index } \\
(\mathbf{D})\end{array}$ \\
\hline Tree & 2.00 & 0.17 \\
Pole & 2.33 & 0.13 \\
Sapling & 1.88 & 0.20 \\
Seedling & 0.87 & 0.46 \\
\hline
\end{tabular}


The condition of vegetation in Selo, including composition and diversity, can be used as an indicator of the sustainability of dry land, especially in terms of soil and water conservation. This study found that tree diversity was in the medium category. Trees play an important role in agricultural landscapes with steep slopes. Vegetation affects the ability of the soil to retain water to prevent erosion and landslides (Wang et al. 2013).

Vegetation types and cover play an important role in controlling runoff (Blinkova and Lavrov 2017). According to Kazemi et al. (2018), high biodiversity can reduce the risk of soil erosion. Allen et al. (2016) found that vegetation diversity could significantly reduce erosion rates by $23 \%$. Vegetation diversity reduces erosion rates indirectly through positive effects on roots. The speciesrich and diverse vegetation community have a larger root morphology so that it can control erosion (Ford et al. 2016). The results of the study by Chang et al. (2019) also showed that the development of vegetation roots could significantly reduce the total amount of runoff.

Vegetation can control soil erosion through canopy, litter, and roots. Vegetation canopy can block raindrops and reduce their kinetic energy as they fall to the ground, thereby reducing the risk of soil damage and erosion rate. The litter layer produced by trees can also reduce surface runoff and increase infiltration (Maridi et al. 2014)

In conclusion, there are 19 vegetation species from 11 families with Fabaceae having the highest number of species. Tree species with the highest IVI are Toona sureni (71.49), Artocarpus heterophyllus (60.60), and Casuarina junghuhniana (50.85), respectively. The Shanon-Wiener Diversity Index shows that the vegetation at tree, pole, and sapling has a moderate diversity, while seedling-stage vegetation has a low diversity.

\section{ACKNOWLEDGEMENTS}

The author would like to thank the Boyolali District government, Indonesia for providing the opportunity to conduct this study. The author's deepest gratitude also to Gilang and Itsla as the survey team who assisted in conducting this study.

\section{REFERENCES}

Akinyemi FO, Kgomo MO. 2019. Vegetation dynamics in African drylands: an assessment based on the vegetation degradation index in an agro-pastoral region of Botswana. Reg Environ Ch 19: 2027-2039.

Allen DC, Cardinale BJ, Thompson TW. 2016. Plant biodiversity in reducing fluvial erosion are limited to low species richness. Ecology 97: 17-24.

Badan Pusat Statistik [BPS]. 2018. Kecamatan Selo dalam Angka 2018. Badan Pusat Statistik, Boyolali. [Indonesian]

Blinkova O, Lavrov V. 2017. Study of soil water-erosion intensity and vegetation cover of an oak-spruce forest in the Pokutsko-Bukovina Carpathians, Ukraine. Arch Biol Sci 69: 627-636.

Boeck HJD, Bloor JMG, Kreyling J, Ransijn JCG, Bijs I, Jentsch A, Zeiter M. 2018. Patterns and drivers of biodiversity-stability relationships under climate extremes. J Ecol 106: 890-902.

Chang E, Li P, Li Z, Su Y, Zhang Y, Zhang J, Liu Z, Li Z. 2019. The impact of vegetation successional status on slope runoff erosion in the Loess Plateau of China. Water 11: 1-21.
Curtis JT, McIntosh RP. 1951. An upland forest continuum in the prairieforest border region of Wisconsin. Ecology 32: 476-496.

Donia J, Hodel E, Liniger H, Subhatu AT. 2019. Land degradation assessment using landscape unit approach and normalized difference vegetation index in Northwest of Tunisia. J Mediterr Ecol 17: 3-13

Fitria A, Banowati E. 2018. Community participation toward the preservation of the forest slopes of Merapi through a program agroforestry coffee in the Village Tlogolele Selo Sub-district. Proceeding of the International Conference on Rural Studies in Asia. Semarang, 11-12 Oktober 2018. [Indonesia]

Ford H, Garbutt A, Ladd Cai, Malarkey J, Skov MW. 2016. Soil stabilization linked to plant diversity and environmental context in coastal wetland. J Veg Sci 27: 259-268.

Geng S, Shi P. Song M, Zong N, Zu J, Zhu W. 2019. Diversity of vegetation composition enhances ecosystem stability along elevational gradients in the Taihang Mountains, China. Ecol Indict 104: 594-603.

Gyssels G, Poesen J, Bochet E, Li Y. 2005. Impact of plant roots on the resistance of soils to erosion by water: a review. Prog Phys Geogr 29: 189-217.

Hakim L, Siswanto D, Rahardi B, Zayadi H. 2019. Fostering coffee agroforestry for agrotourism development in degraded land in a buffer zone of a national park: A case study from Poncokusumo, Malang, Indonesia. Eurasia J Biosci 13: 1613-1620.

Hall RM, Penke N, Kriechbaum M, Kratschmer S, Jung V, Chollet S, Guernion M, Nicolai A, Burel F, Fertil A, Lora A, Cuesta RS, Guzman G, Gomez J, Popescu D, Hoble A, Bunea CI, Zaller JG, Winter S. 2020. Vegetation management intensity and landscape diversity alter plant species richness, functional traits and community composition across European vineyards. Agric Syst 177: 1-14.

Ismail SN, Subehi L, Mansor A, Mashhor M. 2019. Invasive aquatic plant species of Chenderoh Reservoir, Malaysia and Jatiluhur Reservoir, Indonesia. IOP Conf Ser Earth Environ Sci 380: 012004. DOI: 10.1088/1755-1315/380/1/012004. [Malaysian]

Kazemi H, Klug H, Kamkar B. 2018. New service and roles of biodiversity in modern agroecosystems: A review. Ecol Indict 93: 1126-1135.

Kusmana C. 2017. Metode Survey dan Interpretasi Data Vegetasi. IPB Press, Bogor. [Indonesian]

Latifah S, Muhdi, Purwoko A, Tanjung E. 2018. Estimate of aboveground tree biomass Toona sureni and Coffee arabica in agroforestry system of Simalungun, North Sumatra, Indonesia. Biodiversitas 19: 670-675.

Latifah S, Purwoko A, Hartini KS, Sadeli A, Tambal TNR. 2019. The practice of agroforestry Toona sureni merr by the community of Simaungun District, North Sumatra. IOP Conf Ser Earth Environ Sci 374: 012035. DOI: 10.1088/1755-1315/374/1/012035. [Indonesian]

Lestari ND, Suprayogo D, Rachmansyah. 2018. Local biodiversity conservation in Sigi, Central Sulawesi, Indonesia: analysis of the effect of elevation, land accessibility, and farmer's income and perception on vegetation diversity in agroforestry system. Biodiversitas 20: 283-291.

Maridi, Agustina P, Saputra A. 2014. Vegetation analysis of Samin watershed, Central Java as water and soil conservation effort. Biodiversitas 15: 215-223

Miri A. Dragovich D, Dong Z. 2017. Vegetation morphologic and aerodynamic characteristics reduce aeolian erosion. Sci Rep 7: 12831. DOI: 10.1038/s41598-017-13084-x.

Nurhadi, Suparmini, Sutrisnowati SA, Septiana ME, Praptiwi NY. 2019. Farmers household multidimensional level and its effect on participation in agricultural land conservation in disaster residents. IOP Conf Ser Earth Environ Sci 271: 012007. DOI: 10.1088/17551315/271/1/012007. [Indonesian]

Ochoa PA, Fries A, Mejia D, Ruiz-Sinoga JD, Cerda A. 2016. Effects of climate, land cover and topography on soil erosion risk in a semiarid basin of the Andes. Catena 140: 31-42.

Odum PE. 1971. Fundamentals of Ecology. WB Saunders Co. Philadelphia.

Saikia P, Khan ML. 2016. Tree species diversity and its population and regeneration status in homegardens of Upper Assam, Northeast India. J For Environ Sci 32: 129-139.

Sepulveda RB, Carrillo AA. 2015. Soil erosion and erosion thresholds in an agroforestry system of coffee (Coffea arabica) and mixed shade trees (Inga spp. and Musa spp.) in Northern Nicaragua. Agric Ecosyst Environ 210: 25-35. 
Shankar U. 2001. A case high tree diversity in a sal (Shorea robusta) dominated lowland forest of Eastern Himalaya: floristic composition, regeneration and conservation. Curr Sci 81: 776-786.

Soerianegara I, Indrawan A. 2002. Ekologi Hutan Indonesia. Fakultas Kehutanan IPB, Bogor. [Indonesian]

Song Z, Seitz S, Li J, Goebes P, Schmidt K, Kuhn P, Shi X, Scholten T. 2019. Tree diversity reduced soil erosion by affecting tree canopy and biological soil crust development in a subtropical forest experiment. For Ecol Manag 444: 69-77.

Sunardi, Sulistijorini, Setyawati T. 2017. Invasion of Acasia decurrens Wild. after eruption of Mount Merapi, Indonesia. Biotropia 24: 35-46.

Suryawan D, Sutyarto E, Umaya R, Kurnia A, Handiyan Y. 2015 Distribution of invasive alien species of Acasia decurrens in Mount Merapi, Indonesia. Pros Sem Nas Masy Biodiv Indon 1: 738-742. [Indonesian]

Susilowati A, Elfiati D, Rachmat HH, Yulita KS, Hadi AN, Kusuma YS, Batu SAL. 2020. Vegetation structure and floristic composition of tree species in the habitat of Scaphium macropodum in Gunung Leuser National Park, Sumatra, Indonesia. Biodiversitas 21: 30253033 .

Syahidah K, Sumarno, Hartati S. 2016. Pemetaan status kerusakan lahan pertanian di Kecamatan Selo, Kabupaten Boyolali. Agrosains 18: 6 11. [Indonesian]

Tarigan DS. 2019. Biodiversity-based ecosystem services for the management of monoculture plantation landscape using a transdisciplinary approach: a review. IOP Conf Ser Earth Environ Sci 325: 012013. DOI: 10.1088/1755-1315/325/1/012013.

Ulfah M, Fajri SN, Nasir, Hamsah K, Purnawan S. 2019. Diversity, evenness, and dominance index reef fish in Krueng Raya Water, Aceh Besar. IOP Conf Ser Earth Environ Sci 348: 012074 DOI: 10.1088/1755-1315/348/1/012074.

Wang C, Zhao C, Xu ZL, Wang Y, Peng HH. 2013. Effect of vegetation on soil water retention and storage in a semi-arid alpine forest catchment. J Arid Land 5: 207-219.

Wijitkosum S. 2012. Impacts of land use changes on soil erosion in $\mathrm{Pa}$ Deng Sub-district, adjacent area of Kaeng Krachan National Park, Thailand. Soil Water Res 7: 10-17.

Yam G, Tripathi OP. 2016. Tree diversity and community characteristic in Talle Wildlife Sanctuary, Arunachal Pradesh, Eastern Himalaya, India. J Asia-Pac Biodiv 9: 160-165.

Yudaputra A, Rahardjo P. 2020. Short communication: plant species richness and diversity in Karangsambung-Karangbolong National Geopark, Indonesia. Biodiversitas 21: 1735-1742.

Zhang Q, Wang Z, Wu B, Shen N, Liu J. 2018. Identifying sediment transport capacity of raindrop-impacted overland flow within transport-limited system of interrail erosion process on step loess hillslopes of China. Soil Till Res 184: 109-117.

Zhao C, Gao J, Huang Y, Wang G, Zhang M. 2015. Effect of vegetation stems on hydraulics of overland flow under varying water discharges. Land Degrad Dev 27: 1-10. 